\title{
TINGKAT PENDIDIKAN TENAGA KERJA, PENGELUARAN PEMERINTAH SEKTOR PENDIDIKAN, DAN PERTUMBUHAN EKONOMI DI INDONESIA TAHUN 2008-2012
}

\author{
Iga Petiana \\ Iga_fe@feunj.ac.id \\ Fakultas Ekonomi Universitas Negeri Jakarta \\ Dicky Iranto \\ dicky@unj.ac.id \\ Fakultas Ekonomi Universitas Negeri Jakarta \\ Agus Wibowo \\ agus-wibowo@unj.ac.id \\ Fakultas Ekonomi Universitas Negeri Jakarta
}

\begin{abstract}
This research was conducted by observing the level of education graduate workforce, government spending and education sector gross regional domestic product per capita on the basis of constant prices of 2000. In particular the period of 2008-2012 by ex post facto method. The form of panel research data i.e. the combination of the form of time series and cross section. Data on GDP per capita over the constant prices of 2000 and the education level of the labour ditamatkan taken from the Central Bureau of statistics (BPS). Data on government spending on the education sector budget data taken from the income and expenditure of the State (APBN) Indonesia to education sector of the Ministry of Finance of the Republic of Indonesia. Processing data using Eviews 7.0 program and Microsoft Excell. Based on the results of the regression, the influential education variable is positive and significant at levels significantly below 0.05 and variable expenses of government education sector a positive and significant effect on under 0.05 i.e. against economic growth. The value Fhitung (7.360407) Ftabel $>$ (3.90) so summed up these two variables, namely educational level of manpower and Government spending education sector together effect on Indonesia's economic growth. The value of R2 0.568211 signaling that $56,82 \%$ economic growth in Indonesia could be explained both the variable indipenden.
\end{abstract}

Keywords: economic growth, education, employment and Government spending on Education Sector. 


\section{PENDAHULUAN}

Indonesia merupakan negara yang kaya akan sumber daya alam dan sumber daya manusia (SDM). Kekayaan ini seharusnya membuat Indonesia menjadi negara maju, namun kenyataannya tidak. Salah satu penyebabnya adalah ketergantungan terhadap kekayaan alam tanpa diimbangi peningkatan kemampuan SDM untuk mengelolanya. Hal ini mengindikasikan bahwa Indonesia hanya kaya akan sumber daya dari segi kuantitas bukan kualitasnya. Terbukti dari data Human Development Index (HDI), pada tahun 2010 Indonesia berada di urutan 106 dari 169 negara di dunia (Fauziah Rahmah Lubis, 2012:2).

Pertumbuhan ekonomi bagi negara berkembang seperti Indonesia, sangat urgen guna mempercepat pertumbuhan ekonomi merupakan sasaran yang harus dicapai agar dapat sejajar dengan negara-negara maju. Tanpa pertumbuhan ekonomi, tidak akan terjadi peningkatan kesejahteraan, kesempatan kerja, produktivitas, dan distribusi pendapatan. Sebagaimana pertumbuhan ekonomi, pembangunan ekonomi juga mutlak diperlukan guna meningkatkan taraf hidup dan kesejahteraan masyarakatnya.

Tabel 1

Laju Pertumbuhan Ekonomi Indonesia

Tahun 2008 - 2012

\begin{tabular}{|r|c|}
\hline Tahun & $\begin{array}{c}\text { Laju Pertumbuhan } \\
(\%)\end{array}$ \\
\hline 2008 & 6.01 \\
\hline 2009 & 4.58 \\
\hline 2010 & 6.10 \\
\hline 2011 & 6.46 \\
\hline 2012 & 6.50 \\
\hline
\end{tabular}

Sumber: Badan Pusat Statistik (data diolah)

Berdasarkan tabel di atas diketahui bahwa pertumbuhan ekonomi Indonesia pada tahun 2008 mencapai 6,01\% kemudian mengalami penurunan drastis yang terjadi pada tahun 2009 menjadi 4,58\%. Pada tahun 2009 krisis global membawa dampak bagi laju pertumbuhan ekonomi Indonesia, sehingga persentase laju pertumbuhan ekonomi Indonesia menurun. Tahun 2010 pertumbuhan ekonomi meningkat dengan laju pertumbuhan 6,10\%, tahun 2011 juga 
mengalami peningkatan dengan laju $6,46 \%$, dan terus meningkat pada tahun 2012 dengan laju pertumbuhan ekonomi $6,50 \%$.

Pertumbuhan ekonomi Indonesia yang cukup tinggi tersebut dinilai bersifat semu oleh para ekonom. Sebab pembangunan ekonomi suatu bangsa tidak saja diukur dari aspek besaran kuantitatif jumlah dan nilai investasi saja. Namun yang perlu diperhatikan apakah pertumbuhan ekonomi tersebut memiliki economic effect pada proses pemberdayaan dan kualitas masyarakat secara keseluruhan. Ternyata pertumbuhan ekonomi Indonesia tidaklah berdampak menggerakkan sektor riil dan meningkatkan kesejahteraan. Angka-angka pertumbuhan dan realisasi investasi itu sama sekali menunjukkan indikator simbolik. Pemerintah memang telah berhasil meningkatkan pertumbuhan ekonomi hingga di atas $6 \%$. Namun pencapaian target pertumbuhan tersebut tidak dapat menggerakkkan sektor riil dan meningkatkan kesejahteraan rakyat (Sadono Sukirno,2004:29).

Berdasarkan data dari Badan Pusat Statistik menujukkan bahwa laju pertumbuhan ekonomi Indonesia mengalami tidak stabil karna disebabkan banyak faktor yang mempengaruhi pertumbuhan ekonomi. Adapun beberapa faktor yang dapat mempengaruhi pertumbuhan ekonomi adalah tingkat pendidikan tenaga kerja, pengeluaran pemerintah sektor pendidikan, sumber daya alam, sumber daya manusia, investasi atau penanaman modal dan ilmu pengetahuan teknologi.

Pertumbuhan suatu perekonomian tidak lepas dari peran pendidikan yang akan meningkatkan dan mempertinggi kualitas tenaga kerja, sehingga memungkinkan tersedianya angkatan kerja yang lebih terampil, handal, dan sesuai dengan tuntutan pembangunan nasional. Untuk memperbaiki kualitas tenaga kerja diperlukan pendidikan sebagai salah satu modal dasar manusia untuk mencapai pembangunan 
ekonomi yang berkelanjutan. Pendidikan memainkan peranan utama dalam membentuk kemampuan sebuah negara berkembang untuk menyerap teknologi modern dan untuk mengembangkan kapasitas agar tercipta pertumbuhan serta pembangunan yang berkelanjutan.

Namun kenyataannya, tingkat pendidikan angkatan kerja yang ada masih relatif rendah. Stuktur pendidikan angkatan kerja Indonesia masih didominasi pendidikan dasar yaitu sekitar 51,5 persen. Pada tahun 2011, jumlah mahasiswa Indonesia baru mencapai 4,8 juta orang. Bila dihitung terhadap populasi penduduk berusia 19-24 tahun, maka angka partisipasi kasarnya baru 18,4 persen. Jumlah ini masih tertinggal dibandingkan negaranegara lain, terutama negara maju.

Pendidikan tenaga kerja diyakini sangat berpengaruh terhadap produktivitas tenaga kerja karena pendidikan membuat tenaga kerja memiliki pengetahuan untuk berkerja secara efisien. Berdasarkan data Badan Pusat Statistik pada tahun 2008, tenaga kerja Indonesia masih didominasi oleh tenaga kerja berpendidikan rendah, sebagaimana yang ditunjukkan oleh tabel berikut:

Tabel 2. Distribusi Tenaga Kerja Menurut Tingkat Pendidikan 2008-2011

\begin{tabular}{|c|c|c|c|c|c|c|}
\hline \multirow{2}{*}{ Tahun } & \multicolumn{5}{|c|}{ Tingkat Pendidikan Yang Ditamatkan (Orang) } \\
\cline { 2 - 7 } & $\begin{array}{c}\text { Tidak } \\
\text { Sekolah/ } \\
\text { Tidak Tamat } \\
\text { SD }\end{array}$ & Dasar & $\begin{array}{l}\text { Menengah } \\
\text { Umum }\end{array}$ & $\begin{array}{l}\text { Menengah } \\
\text { Kejuruan }\end{array}$ & Tinggi & Jumlah \\
\hline $\mathbf{2 0 0 8}$ & 17.972 .380 & 53.977 .446 & 11.566 .183 & 6.282 .325 & 5.149 .784 & 94.948 .118 \\
\hline $\mathbf{2 0 0 9}$ & 17.088 .807 & 53.286 .068 & 12.919 .107 & 6.250 .260 & 5.912 .693 & 95.456 .935 \\
\hline $\mathbf{2 0 1 0}$ & 16.305 .255 & 56.764 .075 & 12.746 .551 & 5.858 .401 & 5.908 .859 & 97.583 .141 \\
\hline $\mathbf{2 0 1 1}$ & 18.652 .556 & $56 . .359 .342$ & 13.899 .839 & 6.708 .513 & 6.429 .607 & 102.049 .857 \\
\hline
\end{tabular}

Sumber: Badan Pusat Statistik (BPS)

Tabel 2 memperlihatkan masih tingginya partisipasi tenaga kerja dengan pendidikan dasar, dibandingkan dengan tingkat 
pendidikan menengah dan tinggi. Untuk tenaga kerja dengan pendidikan menengah, lulusan Sekolah Menengah Kejuruan (SMK) jauh lebih kecil dibandingkan dengan sekolah umum. Dari seluruh tenaga kerja yang ada, partisipasi tenaga kerja berpendidikan tinggi menduduki posisi paling rendah dibandingkan dengan yang lainnya. Pemerintah Indonesia juga harus dipercaya untuk memikul peranan lebih besar dan lebih menentukan di dalam upaya pengelolahan perekonomian nasional dan daerah (Dumairy, 1996:161). Pengeluaran pemerintah merupakan suatu jenis kebijakan yang dapat dilakukan pemerintah sebagai salah satu langkah untuk mensejahterakan masyarakatnya dan menuju pertumbuhan ekonomi. Pengeluaran pembangunan diwujudkan dalam bentuk pembangunan dan perbaikan prasarana sosial dalam bidang pendidikan dan bidang kesehatan, seperti pembangunan gedunggedung sekolah dan pembangunan rumah sakit.
Berdasarkan data dari Kementrian Keuangan, diketahui bahwa rincian anggaran pengeluaran pemerintah pusat untuk bidang pendidikan terus mengalami peningkatan dari tahun ke tahun. Amandemen UUD 1945 yang mengamanatkan bahwa anggaran pendidikan dialokasikan minimal 20\% dari Anggaran Pendapatan dan Belanja Negara (APBN) serta Anggaran Pendapatan dan Belanja Daerah (APBD). Keseriusan pemerintah pada sektor pendidikan ini terlihat dari alokasi dana APBN untuk sektor pendidikan yang mengalami kenaikan. Walaupun terjadi penurunan persentase alokasi APBN dari tahun 2007 sampai dengan 2008, namun alokasi dana APBN kembali mengalami kenaikan pada tahun 2009 dengan alokasi sebesar $19,76 \%$ dari dana APBN. Adapun jumlah alokasi anggaran pendidikan terhadap dana APBN dapat dilihat dari tabel di bawah ini : 
Tabel 3. Alokasi Anggaran Pendidikan 2005-2009

\begin{tabular}{|c|c|c|}
\hline Tahun & $\begin{array}{c}\text { Alokasi } \\
\text { (miliar } \\
\text { Rupiah) }\end{array}$ & $\begin{array}{c}\text { Persentase } \\
\text { Dari APBN } \\
(\%)\end{array}$ \\
\hline 2005 & $23.117,4$ & 19,23 \\
\hline 2006 & $37,095,1$ & 22,44 \\
\hline 2007 & $40.476,8$ & 18,95 \\
\hline 2008 & $45.296,7$ & 16,67 \\
\hline 2009 & $62.098,3$ & 19,76 \\
\hline
\end{tabular}

Sumber : Kementrian Keuangan RI (data diolah)

Seiring dengan alokasi dana pendidikan yang meningkat, pembangunan pendidikan juga telah menunjukkan hasil yang memuaskan. Upaya perluasan akses pendidikan telah berhasil meningkatkan angka partisipasi kasar (APK) jenjang PAUD dari $39,09 \%$ pada tahun 2004 menjadi $53,09 \%$ pada tahun 2009. Pada jenjang SD/MI paket A terjadi peningkatan angka partisipasi kasar (APK) dari 112,5\% pda tahun 2004 menjadi $116,95 \%$ pada tahun 2009 dan angka partisipasi murni (APM) dari $94,12 \%$ pada tahun 2004 menjadi 95,40\% pada tahun 2009. Sementara itu tingkat literasi penduduk usia lebih 15 tahun meningkat dari $89,79 \%$ pada tahun 2004 menjadi 95,05\% pada tahun 2009 (BPS, 2009).
Pertumbuhan ekonomi sendiri dipengaruhi oleh sumber daya alam. Sumber daya alam merupakan faktor utama dalam pertumbuhan ekonomi suatu negara. Kekayaan alam akan dapat mempermudah usaha untuk mengembangkan perekonomian suatu negara, terutama pada masamasa permulaan dari proses pertumbuhan ekonomi. banyak daerah yang sangat bertumpu pada kekayaan alamnya untuk kemajuan ekonomi. Di negara kurang berkembang, sumber daya alam sering terbengkalai, kurang atau salah pemanfaatan. Tersedianya sumber daya alam melimpah saja belumlah cukup bagi pertumbuhan ekonomi karena diperlukan secara tepat (M.L. Jhingan, 2003:68). Jika sumber daya alam yang ada tidak dipergunakan secara tepat, negara itu tidak mengalami kemajuan. Tetapi jika hanya bertumpu pada kekayaan alam saja, itu tidak menjamin suatu daerah akan mengalami pertumbuhan ekonomi. jika tidak ada sumber daya alam maka tidak ada yang diolah oleh 
sumber daya manusia. Sumber daya alam sangat mempengaruhi pertumbuhan industri suatu daerah, terutama dalam hal penyediaan bahan baku produksi.

Suatu daerah yang memiliki kekayaan alam belum tentu dapat mengembangkan perekonomiannya jika tidak didukung oleh sumber daya manusia yang baik. Sumber daya manusia merupakan faktor penting yang diperlukan dalam mengolah sumber daya alam. Penduduk yang bertambah dari waktu ke waktu dapat menjadi pendorong maupun penghambat dalam pertumbuhan ekonomi. penduduk yang bertambah akan memperbesar jumlah tenaga kerja dan penambahan tersebut memungkinkan suatu daerah untuk menambah produksi. Namun di sisi lain, akibat buruk dari penambahan penduduk yang tidak diimbangi oleh kesempatan kerja akan menyebabkan pertumbuhan ekonomi tidak sejalan dengan peningkatan kesejahteraan.

Pertumbuhan ekonomi juga dapat ditunjukkan oleh pertam- bahan produksi atau pertumbuhan pendapatan nasional. Dalam menciptakan pertumbuhan ekonomi dibutuhkan adanya penanaman modal atau investasi, dimana investasi merupakan kebutuhan dalam pembangunan yang menghendaki adanya pertumbuhan. Investasi dapat dilakukan bukan saja pada fisik, tetapi juga pada bidang non fisik. Investasi fisik meliputi bangunan pabrik dan perumahan karyawan, mesin-mesin dan peralatan, serta persediaan (bahan mentah, barang setengah jadi, dan barang jadi). Investasi non fisik meliputi pendidikan, pelatihan, migrasi, pemeliharaan kesehatan dan lapangan kerja.

Faktor lain yang mempengaruhi tingkat pertumbuhan ekonomi adalah kemajuan teknologi. Kemajuan teknologi berkaitan dengan perubahan di dalam metode produksi yang merupakan hasil pembaharuan atau hasil dari teknik penelitian baru. Dengan perkembangan teknologi yang semakin pesat mendorong pula pergantian pola kerja yang 
semula banyak menggunakan tangan/manual kini berahli ke penggunaan mesin yang canggih yang lebih memiliki efisien, kualitas dan kuantitas yang jauh lebih tinggi dibandingkan penggunaan manual hal ini dapat berakibat pada semakin cepatnya pertumbuhan ekonomi. tanpa adanya perkembangan teknologi, produktivitas barang-barang akan modal tidak mengalami perubahan dan tetap berada pada tingkat yang sangat rendah. Oleh karena itu pendapatan perkapita hanya mengalami perkembangan yang sangat kecil sekali.

Berdasarkan penjelasan latar belakang masalah di atas, maka peneliti tertarik untuk meneliti tentang pengaruh tingkat pendidikan tenaga kerja dan pengeluaran pemerintah sektor pendidikan terhadap pertumbuhan ekonomi di Indonesia tahun 20082012.

KAJIAN TEORETIK

Pertumbuhan Ekonomi

Produk Domestik Bruto
(PDB) merupakan alat pengukur pertumbuhan ekonomi di suatu negara. Pertumbuhan ekonomi adalah suatu variabel ekonomi makro yang memiliki teori-teori yang pada dasarnya menjelaskan faktor-faktor yang menentukan pertumbuhan ekonomi serta bagaimana keterkaitan antara faktor-faktor tersebut sehingga terjadi proses pertumbuhan. Kuznet mendefinisikan pertumbuhan ekonomi suatu negara sebagai kemampuan untuk menyediakan barang-barang ekonomi yang terus meningkat bagi penduduknya (Suryana, 2000:64).

Pertumbuhan kemampuan ini berdasarkan kepada kemajuan teknologi, kelembagaan (institusional) serta penyesuaian ideologi yang dibutuhkannya. Definisi tersebut memiliki tiga komponen penting, yaitu: (1) Pertumbuhan ekonomi suatu bangsa terlibat dari meningkatnya persediaan barang secara terus-menerus yang merupakan manivestasi pertumbuhan ekonomi. Kemampuan untuk menyediakan berbagai macam 
barang adalah tanda kematangan ekonomi; (2) Teknologi maju merupakan faktor dalam pertumbuhan ekonomi yang menentukan derajat kemampuan pertumbuhan dalam menyediakan aneka macam barang kepada penduduk, dan (3) Penggunaan teknologi secara luas dan efisien memerlukan adanya penyesuaian di bidang kelembagaan dan ideologi sehingga inovasi yang dihasilkan oleh ilmu pengetahuan dapat dimanfaatkan secara tepat. Dengan kata lain pertumbuhan ekonomi yang cepat memungkinkan penelitian dasar ilmiah dan pada gilirannya membawa penemuanpenemuan dan pembaruanpembaruan teknologi yang mendorong pertumbuhan ekonomi pada masa selanjutnya.

Lebih lanjut pertumbuhan ekonomi diartikan sebagai kenaikan Produk Domestik Bruto/Pendapatan Nasional Bruto tanpa memandang apakah kenaikan tersebut lebih besar atau lebih kecil dari tingkat pertumbuhan penduduk atau apakah perubahan struktur ekonomi terjadi atau tidak. Pertumbuhan ekonomi merupakan salah satu indikator penting guna menganalisis pembangunan ekonomi yang terjadi suatu negara. Sedangkan menurut Boediono (1999:12), pertumbuhan ekonomi merupakan tingkatan pertambahan dari pendapatan nasional. Dengan kata lain, pertumbuhan ekonomi adalah sebagai proses kenaikan output per capital dalam jangka panjang dan merupakan ukuran keberhasilan pembangunan.

Pengertian tersebut mencapai tiga aspek, yaitu proses, output perkapita dan jangka panjang. Jadi, pertumbuhan ekonomi merupakan suatu proses bukan gambaran ekonomi atau hasil pada saat itu. Pertumbuhan ekonomi juga berkaitan dengan kenaikan output perkapita yaitu mengenai pertumbuhan GDP dan pertumbuhan penduduk. Pertumbuhan ekonomi dalam prespektif jangka panjang yaitu apabila selama jangka waktu yang cukup panjang tersebut output perkapita menunjukkan kecenderungan yang 
meningkat.

Pertumbuhan ekonomi suatu negara dapat dicapai dengan mengunakan dua cara. Cara yang pertama adalah dengan extensively yaitu menggunakan banyak sumber daya (seperti fisik, manusia atau natural capital). Ketika pertumbuhan ekonomi dicapai dengan menggunakan banyak tenaga kerja, hal tersebut tidak menghasilkan pertumbuhan pendapatan per kapita. Namun, ketika pertumbuhan ekonomi dicapai melalu penggunaan sumber daya yang lebih produktif, termasuk tenaga kerja, hal tersebut menghasilkan pendapatan per kapita yang lebih tinggi dan meningkatkan standar hidup rata-rata masyarakat.

Menurut S. Sukino pertumbuhan ekonomi diartikan sebagai perkembangan kegiatan dalam perekonomian yang menyebabkan barang dan jasa yang diproduksi dalam masyarakat bertambah dan kemakmuran masyarakat meningkat (Sadono,2004:332). Jadi pertumbuhan ekonomi mengukur prestasi dari perkembangan suatu perekonomian dari suatu periode ke periode lainnya. Kemampuan suatu negara untuk menghasilkan barang dan jasa akan meningkat. Kemampuan yang meningkat ini disebabkan oleh pertambahan faktor-faktor produksi dalam jumlah dan kualitasnya. Investasi akan menambah barang modal dan teknologi yang digunakan juga semakin berkembang. Disamping itu, tenaga kerja bertambah sebagai akibat perkembangan penduduk seiring dengan meningkatnya pendidikan dan keterampilan mereka.

Gambaran secara menyeluruh tentang kondisi perekonomian suatu daerah dapat diperoleh dari PDRB (Produk Domestik Regional Bruto). Sebagai salah satu indicator makro ekonomi, PDRB merupakan jumlah nilai tambah yang timbul dari seluruh sektor perekonomian di suatu wilayah tertentu atau merupakan jumlah nilai barang dan jasa akhir yang dihasilkan oleh seluruh unit ekonomi (BPS, 2011:1).

Berdasarkan beberapa pen- 
dapat di atas, dapat disimpulkan bahwa pertumbuhan ekonomi adalah suatu proses perkembangan perekonomian suatu negara yang ditandai dengan peningkatan produksi barang dan jasa riil, yang diukur dengan PDB pada perekonomian nasional dan PDRB perekonomian daerah.

\section{Tingkat Pendidikan}

Hasil temuan Payaman menyebutkan bahwa kemajuan suatu daerah sangat dipengaruhi oleh kemampuan tenaga kerja dan tingkat pendidikan mereka. Semakin tinggi tingkat pendidikan para tenaga kerja, simpul Payaman, maka diharapkan akan meningkatkan produktifitas mereka. Senada dengan Payaman, Diryarkara bahkan dengan tegas menyatakan bahwa pendidikan merupakan kerja memanusiakan manusia (Fuad Ihsan, 2008:4).

$$
\text { Memperkuat pendapat }
$$

Payaman dan Driyakara, Wasty Soemanto (2008:21), sampai pada kesimpulan bahwa pendidikan merupakan proses guna meng- hasilkan pengalaman yang memberikan kesejahteraan pribadi, baik lahiriah maupun batiniah. Istilah pengalaman, lanjut Wasty Soemanto, dapat diartikan sebagai proses dan sebagai hasil meliputi tiga aspek yaitu, pengalaman yang berupa pengetahuan, pengalaman yang berupa keterampilan dan pengalaman yang berupa sikap atau nilai. Wasty Soemanto juga menyimpulkan bahwa pendidikan berfungsi memberikan kondisi yang menunjang perkembangan segala aspek kepribadian manusia. Dalam bahasa yang filosofis, pendidikan itu pertolongan agar manusia dapat mengembangkan potensi dan kapasitas pribadi yang ada; yang pada akhirnya dapat hidup sendiri secara mandiri dan bertanggungjawab atas kesejahteraan hidup mereka.

Berdasarkan pengertian dan fungsi di atas, dapat ditarik benang merah bahwa pendidikan merupakan usaha agar sadar yang dilakukan oleh keluarga, masyarakat, dan pemerintah melalui kegiatan bimbingan, pengajaran, 
dan latihan, yang berlangsung sepanjang hayat untuk mempersiapkan modal manusia di masa yang akan datang dalam memperoleh kesejahteraan hidup. Salah satu upaya untuk mencapai kesejahteraan hidup manusia, dengan memilih pendidikan terbaik dan memperoleh pengajaran sampai ketingkat pendidikan formal yang lebih tinggi.

Definisi tingkat pendidikan menurut BPS (2014) adalah jenjang pendidikan tertinggi yang ditamatkan oleh seseorang, yang ditandai dengan sertifikat/ijazah. Artinya ijazah pendidikan seseorang diterakhir menjadi legalitas tingkat pendidikan tertinggi yang ditempuh. BPS juga menegaskan bahwa tenaga kerja yang berkualitas merupakan salah satu faktor penunjang keberhasilan pembangunan. Pendidikan merupakan salah satu jalan untuk meningkatkan kemampuan tenaga kerja tersebut. Menurut UndangUndang Sistem Pendidikan Nasional (UU Sisdiknas) No. 20 tahun 2003, tingkat pendidikan terdiri dari jenjang pendidikan dan kesesuaian jurusan. Jenjang pendidikan adalah tahapa pendidikan yang ditetapkan berdasarkan tingkat perkembangan peserta didik, tujuan yang akan dicapai, dan kemampuan yang dikembangkan, terdiri dari: (1) Pendidikan dasar, yaitu jenjang pendidikan awal selama 9 (Sembilan) tahun pertama masa sekolah anak-anak, yang melandasi jenjang pendidikan menengah; (2) Pendidikan menengah, yaitu jenjang pendidikan lanjutan pendidikan dasar, dan (3) Pendidikan tinggi, yaitu jenjang pendidikan setelah pendidikan menengah yang mencakup program sarjana, magister, doktor, dan spesialis yang diselenggarakan oleh perguruan tinggi.

Menurut Ace Suryadi (1999:239), tenaga kerja terdidik lebih produktif dibandingkan dengan angkatan kerja tidak terdidik. Hal ini dapat dijelaskan bahwa semakin tinggi tingkat pendidikan pekerja semakin tinggi produktivitasnya yang tercermin dalam penghasilan, artinya tamatan 
jenjang pendidikan yang lebih tinggi menunjukkan tingkat produktivitas rill yang lebih tinggi pula. Lebih lanjut Sadono Sukirno (2004) menyimpulkan bahwa pendidikan sejatinya merupakan suatu bentuk investasi sumber daya manusia. Di satu pihak untuk memperoleh pendidikan diperlukan waktu dan uang. Tetapi pada masa mendatang setelah pendidikan diperoleh, masyarakat dan individu akan memperoleh manfaat. Pendek kata, individu yang memperoleh pendidikan tinggi cenderung memperoleh pendapatan yang lebih tinggi dibandingkan dengan tidak berpendidikan. Semakin tinggi pendidikan, semakin tinggi pula pendapatan yang diperoleh.

Selanjutnya Mincer (Mohammad Ali, 2009:196), sampai pada kesimpulan bahwa seseorang dengan pendidikan yang lebih tinggi, bisa belajar banyak melalui pengalaman kerjan dan cenderung lebih mampu meningkatkan kemampuannya, sehingga cenderung lebih produktif. Singkatnya, produktivitas kerja atau produk yang dihasilkan oleh seseorang tenaga kerja berbanding lurus dengan akumulasi investasi pendidikan yang bersangkutan. Semakin besar akumulasi investasi sumber daya manusia yang dialami, semakin tinggi produktivitas kerjanya. Sehingga upah atau gaji itu sendiri merupakan imbalan atas nilai yang dihasilkan oleh seorang tenaga kerja. Jadi semakin tinggi produktivitas semakin tinggi pula gaji yang diperolehnya. Ini menunjukkan bahwa investasi dalam capital manusia sangat pending untuk meningkatkan pertumbuhan ekonomi.

Senada dengan Mincer, Theodore W. Schultz (Mohammad Ali, 2009), sampai pada kesimpulan bahwa pendidikan, pelatihan, dan kesehatan merupakan bentuk investasi untuk membuka kesempatan dalam pilihan yang seharusnya tersedia bagi banyak individu. Modal berupa manusia akan berimplikasi pada banyak sektor, terutama pada sektor ekonomi. Teori human capital, lanjut Theodore, dapat diaplikasikan 
dengan syarat adanya sumber teknologi tinggi secara efisien dan adanya sumber daya manusia yang dapat memanfaatkan teknologi yang ada. Teori ini meyakini bahwa pendidikan sebagai investasi dalam meningkatkan produktivitas masyarakat. Dalam kontek tenaga kerja, keterampilan baru yang mereka miliki membuat mampu mengimplementasikan pengetahuannya untuk menggunakan teknologi baru. Hal ini tentu saja dapat meningkatkan hasil produksi, yang pada gilirannya meningkatkan output nasional.

Selanjutnya, Todaro sampai pada kesimpulan bahwa manfaa pendidikan bagi per-tumbuhan ekonomi suatu bangsa secara umum adalah: (1) Dapat menciptakan tenaga kerja yang lebih produktif, karena adanya peningkatan pengetahuan dan keahlian guna meningkatkan pertumbuhan ekonomi;

Tersedianya kesempatan kerja yang lebih luas, dan (3) Terciptanya suatu kelompok pemimpin yang terdidik guna mengisi jabatan- jabatan penting dalam dunia usaha maupun pemerintah. Sementara menurut Schultz, pengembangan sumber daya manusia bagi pertumbuhan ekonomi dapat dilakukan dengan lima cara yaitu: (1) Fasilitas dan pelayanan kesehatan, termasuk di antaranya semua pengeluaran yang mempengaruhi harapan hidup, kekuatan dan stamina tenaga kerja sertas vitalitas rakyat; (2) Latihan jabatan termasuk magang yang diorganisasikan oleh perusahaan;

Pendidikan yang diorganisasikan secara formal pada tingkat dasar, menengah dan tinggi; (4) Program studi bagi orang dewasa yang tidak diorganisasikan oleh perusahaan termasuk program ektension khususnya pada pertanian, dan (5) Migrasi perorangan dan keluarga untuk menyesuaikan diri dengan kesempatan kerja yang selalu berubah (Duane Schultz, 1994:54).

Berdasarkan beberapa studi ekonometrika dapat diketahui bahwa seseorang banyak hal tergantung pada tingkat pendidikannya. Seseorang yang memiliki 
tingkat pendidikan tinggi pada umumnya memperoleh pendapatan yang tinggi. Demikian pula negaranegara yang rata-rata pendidikan masyarakatnya tinggi memperoleh pendapatan yang lebih tinggi dari negara-negara yang rata-rata pendidikan masyarakat rendah. Biaya-biaya yang digunakan untuk pendidikan untuk modal usaha. Jadi proses pendidikan dapat dikatakan sebagai suatu keputusan investasi.

Berdasarkan uraian di atas, dapat ditarik kesimpulan bahwa pendidikan dapat memberi kontribusi bagi pertumbuhan ekonomi. Itu karena peranan pendidikan dalam menciptakan tenaga kerja yang berkualitas, serta menjadi kemajuan suatu daerah yang dipengaruhi oleh kemampuan tenaga kerja; yang juga sangat dipengaruhi oleh tingkat pendidikannya. Semakin tinggi tingkat pendidikan tenaga kerja, maka diharapkan berbanding lurus dengan peningkatan produktifitas mereka. Dengan demikian pendidikan tenaga kerja yang tinggi akan meningkatkan produktivitas, meningkatkan penghasilan yang pada muaranya memberikan sumbangan lebih besar pada pendapatan nasional.

\section{Pengeluaran Pemerintah Sektor Pendidikan \\ Pengeluaran pemerintah}

adalah nilai pembelanjaan yang dilakukan oleh pemerintah yang digunakan untuk kepentingan masyarakat. Sebagai contoh pengeluaran untuk menyediakan fasilitas pendidikan dan kesehatan, pengeluaran untuk menyediakan polisi dan tentara, pengeluaran gaji untuk pegawai pemerintah dan pengeluaran untuk mengembangkan infrastruktur dibuat untk kepentingan masyarakat. Menurut Dumairy (1997:173), pengeluaran pemerintah di Indonesia dapat dibedakan menurut dua klasifikasi, yaitu: (1) Pengeluaran rutin pada dasarnya berusurkan pos-pos pengeluaran untuk membiayai pelaksanaan roda pemerintah sehari-hari, meliputi belanja pegawai; belanja barang; berbagai macam subsidi (subsidi daerah dan 
subsidi harga barang); angsuran dan bunga utang pemerintah; serta jumlah pengeluaran lain. Anggaran belanja rutin memegang peranan yang penting untuk menunjang kelancaran mekanisme sistem pemerintahan serta upaya peningkatan produktivitas, yang pada gilirannya akan menunjang tercapainya sasaran dan tujuan setiap tahap pembangunan, dan (2) Pengeluaran pembangunan, yaitu pengeluaran yang bersifat menambah modal masyarakat dalam bentuk pembangunan baik prasarana fisik dan non fisik. Dibedakan atas pengeluaran pembanguanan yang dibiayai dengan dana rupiah dan bantuan proyek. Pengeluaran pembangunan merupakan pengeluaran yang ditujukan untuk membiayai program-program pembangunan sehingga anggarannya selalu disesuaikan dengan dana yang berhasil dimobilisasi. Dana ini kemudian dialokasikan pada berbagai bidang sesuai dengan prioritas yang telah direncanakan.

Selanjutnya menurut Supar- moko (1994:78), pengeluaran pemerintah dapat dinilai dari berbagai segi, di antaranya: (1) Pengeluaran itu merupakan investasi yang menambah kekuatan dan ketahanan ekonomi dimasa yang akan datang; (2) Pengeluaran itu langsung memberikan kesejahteraan dan kegembiraan bagi masyarakat; (3) Merupakan penghematan pengeluaran yang akan datang, dan (4) Menyediakan kesempatan kerja lebih banyak dan penyebaran tenaga beli yang lebih luas.

Sadono Sukirno (2004:38) sampai pada kesimpulan bahwa pengeluaran pemerintah atas barang dan jasa dapat digolongkan menjadi dua golongan yaitu konsumsi pemerintah dan investasi pemerintah. Pengeluaran dalam golongan konsumsi pemerintah adalah pengeluaran yang dilakukan atas barang dan jasa yang dikonsumsikan, seperti membayar gaji pegawai dan membeli bahan bakar untuk kendaraan pemerintah. Sedangkan golongan investasi pemerintah adalah pengeluaran 
yang digunakan untuk membangun prasarana seperti jalan, jembatan, sekolah, dan rumah sakit. Di dalam APBN dan APBD, pengeluaran pemerintah guna investasi dibagi dalam 21 sektor, yang terdiri dari: (1) Industri; (2) Pertanian dan Kehutanan; (3) Sumber Daya Air dan Irigasi; (4) Tenaga Kerja; (5) Perdagangan, Pengembangan Usaha Daerah, Keuangan di Koperasi; (6) Transportasi, Meteorologi dan Geofisika; (7) Pertambangan dan Energi; (8) Pariwisata, Pos, dan Telekomunikasi; (9) Pembangunan Daerah dan Transportasi; (10) Lingkungan Hidup dan Tata Ruang; (11) Pendidikan, Kebudayaan Nasional, Kepercayaan Terhadap Tuhan YME, Pemuda dan Olahraga; (12) Kependudukan dan Keluaraga Sejahtera;

Kesehatan, Kesejahteraan Sosial, Peranan Wanita, Anak Remaja, dan Remaja; (14) Perumahan dan Pemukiman; (15) Agama; (16) IImu Pengetahuan dan Teknologi; (17) Hukum; (18) Aparatur Pemerintah dan Pengawasan; (19) Politik,
Penerangan, Komunikasi, dan Media Masa; (20) Keamanan dan Ketertiban Umum, dan (21) Subsidi (www.bps.go.id).

Berdasarkan uraian di atas tampak sektor-sektor yang menjadi bagian dari kelompok pengeluaran pemerintah sektor pendidikan. Pada sektor 11 yang dimasuk pendidikan, kebudayaan nasional, dan kepercayaan terhadap Tuhan Yang Maha Esa, serta pemuda dan olahraga misalnya program pembinaan pendidikan tinggi, pendidikan luar sekolah dan kedinasan, dan lain-lain. Dalam hal ini intervensi pengeluaran pemerintah pada sektor pendidikan, akan jelas terlihat pada belanja bagi pertumbuhan yang secara keseluruhan mencerminkan proporsi anggaran pertumbuhan ekonomi. Adapun tujuan pengeluaran pemerintah:

Pendidikan, karena kebanyakan negara-negara dewasa ini mengaku pentingnya tenaga kerja yang terlatih untuk pertumbuhan ekonomi, maka pengeluaranpengeluaran pendidikan mempu- 
nyai peranan penting dalam anggaran belanja;

Pengangkutan, banyaknya perekonomian-perekonomian yang sedang berkembang mengalami kekurangan fasilitas-fasilitas pengangkutan yang diperlukan untuk spesialisasi dalam produksi, industrialisasi dan perdagangan luar negeri;

Kesehatan masyarakat, penyakit teristimewa dala negeri, merupakan perintah utama bagi bertambahnya hasil produksi di banyak Negara tropis, dan perbaikan-perbaikab rumah sakit, fasilitas-fasilitas pengobatan dan pengajaran dasar dalam ilmu kesehatan diperlukan; (4) Perkembangan pertanian, kebanyakan perekonomian yang sedang berkembang terutama mengandalkan diri pada pertanian untuk mata pencaharian dan ekspor; (5) Industri, kebanyakan pemerintah dari perekonomian yang sedang berkembang memandang perekonomian industri sebagai keharusan (Suparman, 1993:73).

Pengeluaran pemerintah mencakup berbagai aspek, namun terdapat aspek dominan yang perlu menjadi perhatian khusus, yakni pendidikan. Karena melalui pendidikan setiap manusia dapat berproses meningkatkan pengetahuan, bakat serta keahlian pada suatu bidang. Peningkatan kualitas manusia akan membentuk kemandirian yang utuh dan tidak bergantung kepada pihak lain. Peningkatan kualitas diri dan kemandirian inilah yang akan menjadi nilai baik investasi dari pengeluaran pemerintah pada sektor pendidikan. Intervensi pemerintah dalam bidang pendidikan diperlukan guna pemerataan akses pendidikan bagi siapa saja dan mempunyai tujuan akhir peningkatan kualitas manusia.

Menurut para ahli ekonomi, kriteria investasi yang tercermin pada pengeluaran pemerintah untuk pendidikan, mestinya meliputi: (1) Kriteria tingkat pengembalian, pendidikan sebagai suatu investasi mempunyai dua komponen. Komponen konsumsi masa depan dan komponen penghasilan masa depan. Investasi dibidang keterampilan dan 
pengetahuan menaikkan penghasilan masa depan, sementara kepuasan yang diperoleh dari pendidikan merupakan komponen konsumsi; (2) Kriteria sumbangan pendidikan pada pendapatan nasional bruto, menurut kriteria ini investasi dibidang pendidikan ditentukan oleh sumbangannya dalam menaikkan pendapatan nasional bruto atau pemebentukan modal fisik dalam satu periode; (3) Kriteria Faktor Residual. Ekonom semisal Solow, Denison, Jorgenson, dan Kuznet, telah mencoba mengukur beberapa proporsi kenaikan produk nasional bruto dalam satu periode. Mereka menyimpulkan bahwa terdapat hubungan antara input modal dan buruh dengan seberapa besar kenaikan pendapatan nasional bruto yang dianggap dari faktor lain-yang sering dikelompokkan sebagai residual. Solow, Denison, Jorgenson, dan Kuznet sampai pada kesimpulan bahwa faktor residual yaitu pendidikan, penelitian, latihan, skala ekonomi dan faktor lainnya memepengaruhi produktivitas manusia.

Selanjutnya Ramirez, dkk (1998) menyatakan bahwa kinerja ekonomi suatu Negara mempengaruhi pembangunan manusia melalui aktivitas rumah tangga dan pemerintah, selain adanya peran civil society seperti melalui organisasi masyarakat dan lembaga swadaya masyarakat. Ramirez juga mengungkapkan bahwa pengeluaran pemerintah memiliki peran penting sebagai penghubung yang menentukan kekuatan hubungan antara pertumbuhan ekonomi dan pembangunan manusia. Artinya pemerintah memegang peran penting dalam menyediakan akses pendidikan kepada masyarakat. Sehingga dengan pendidikan yang diperoleh masyarakat mendapatkan akses pekerjaan dengan pendapatan yang baik.

Dalam Human capital Approach, biaya pendidikan dapat dianggap sebagai pengeluaran yang hasilnya bukan untuk dinikmati sekarang tetapi pada masyarakat yang akan datang. 
Investasi dalam hal pendidikan diperlukan peran pemerintah untuk membangun suatu sarana dan sistem pendidikan yang baik. Alokasi anggaran pengeluaran pemerintah terhadap pendidikan merupakan wujud nyata dari investasi untuk meningkatkan produktivitas masyarakat. Konsekuensi semakin berkualitasnya modal manusia melalui pendidikan adalah menghasilkan masyarakat berproduktivitas tinggi, dapat meningkatkan penghasilan masyarakat sehingga dapat mempertinggi pertumbuhan ekonomi.

Berdasarkan uraian teoriteori di atas, dapat disimpulkan bahwa investasi pemerintah untuk pembangunan, merupakan wujud intervensi pemerintah guna meningkatkan kualitas manusia. Pengeluaran pemerintah pada sektor pembangunan, khususnya pada bidang pendidikan merupakan rangkaian proses dalam peningkatan kualitas manusia yang berujung pada peningkatan pertumbuhan ekonomi.

\section{METODOLOGI PENELITIAN}

Metode penelitian yang digunakan dalam penelitian ini adalah metode expost facto dengan jenis data yang digunakan adalah data sekunder. Jenis data yang digunakan dalam penelitian ini adalah data sekunder yang bersifat kuantitatif yaitu data yang telah tersedia dalam bentuk angka. Sedangkan data yang digunakan dalam penelitian ini adalah data runtun waktu (time series) dan data deret lintang (cross section). Data time series sebanyak lima tahun dari tahun 2008 sampai tahun 2012 dan cross section yaitu 33 provinsi di Indonesia. Data yang digunakan meliputi data tingkat pendidikan yang diperoleh dari Badan Pusat Statistik (BPS), pengeluaran pemerintah sektor pendidikan dengan mengambil data di Kementrian Keuangan RI, dan pertumbuhan ekonomi yang diperoleh dari Badan Pusat Statistik (BPS). Analisis dengan menggunakan panel data adalah kombinasi antar deret waktu (time series) dan deret lintang (cross 
section). Dalam model panel data, persamaan model dengan menggunakan data cross section dapat ditulis sebagai berikut:

$Y i=\beta 0+\beta 1 X i+\beta 2 X i ; i=1,2, \ldots$, N. .......(1)

Di mana $\mathrm{N}$ adalah banyaknya data cross section Sedangkan persamaan model dengan time series adalah:

$Y t=\beta 0+\beta 1 X t+\beta 2 X t ; t=1,2, \ldots$, $\mathrm{T}$

Di mana $T$ adalah banyaknya data time-series. Mengingat data panel merupakangabungan dari time series dan cross section, maka model dapat ditulis dengan: $\mathrm{i}=1$, $2, \ldots, N ; t=1,2, \ldots T$

Keterangan :

$\mathrm{Y}=$ variabel pertumbuhan ekonomi $\mathrm{X} 1=$ tingkat pendidikan tenaga kerja $\mathrm{X} 2=$ pengeluaran pemerintah sektor pendidikan

$\mathrm{i}=$ cross section

$\mathrm{t}=$ time series

$\beta 0=$ konstanta

$\beta 1, \beta 2=$ koefisien yang dicari untuk mengukur pengaruh variabel $\mathrm{X} 1$ dan X2

$=$ kesalahan pengganggu

\section{HASIL DAN PEMBAHASAN}

Hasil perbandingan antara thitung dengan ttabel pada tingkat pendidikan tenaga kerja terlihat bahwa thitung (6.021456) > ttabel (1.97472) dengan signifikansi $(0.0000<0,05)$ lebih kecil dari tingkat signifikansi $5 \%$ hal ini menunjukkan pengaruh positif antara Tingkat Pendidikan Tenaga Kerja dengan Pertumbuhan Ekonomi, ini berarti sesuai dengan teori yang menjelaskan bahwa tingkat pendidikan tenaga kerja memiliki pengaruh yang positif terhadap pertumbuhan ekonomi. Di mana kondisi yang terjadi ketika tingkat pendidikan tenaga kerja meningkat, maka pertumbuhan ekonomi juga meningkat dan sebaliknya ketika tingkat pendidikan tenaga kerja menurun, pertumbuhan ekonomi menurun. Pada data yang diperoleh menunjukkan bahwa tingkat pendidikan tenaga kerja tertinggi diduduki oleh Provinsi DKI Jakarta jika dibandingkan dengan Provinsi lain yang ada di Indonesia, karena 
Provinsi DKI Jakarta menjadi salah satu titik yang cukup besar kontribusinya dalam pertumbuhan ekonomi. Salah satu penyebab tingginya jumlah tingkat pendidikan tenaga kerja disebabkan tingginya modal untuk meningkatkan jenjang pendidikan di Provinsi DKI Jakarta sehingga produktifitas yang dimiliki tenaga kerja meningkat, juga penghasilan yang akan memberikan sumbangan pada pendapatan nasional yang lebih besar.

Berdasarkan hasil perhitungan yang diperoleh, diketahui hasil estimasi sesuai dengan hipotesis awal yang menyatakan bahwa tingkat pendidikan tenaga kerja dengan pertumbuhan ekonomi berpengaruh positif. Artinya bahwa semakin tinggi tingkat pendidikan yang dicapai angkatan kerja maka semakin tinggi pertumbuhan ekonomi. Hal ini sesuai dengan kaidah teori modal manusia bahwa investasi dalam hal pendidikan sebagai investasi dalam meningkatkan produktivitas masyarakat. Pendidikan dan keterampilan baru yang dimiliki tenaga kerja membuat ia mampu mengimplementasikan pengetahuannya untuk menggunakan teknologi baru. Hal ini dapat meningkatkan hasil produksi yang pada akhirnya meningkatkan output nasional. Hasil temuan ini memperkuat penelitian Ramirez dkk, di mana terdapat hubungan positif yang kuat antara pembangunan manusia dan pertumbuhan ekonomi per kapita. Pengeluaran pemerintah untuk sektor pelayanan sosial dan tingkat pendidikan terbukti pula mempunyai peran penting sebagai penghubung yang menentukan kekuatan hubungan antara pertumbuhan ekonomi dan pembangunan manusia.

Hasil penelitian ini juga mendukung temuan Sanusi Fattah, bahwa variabel tingkat pendidikan tenaga bahwa hasil menunjukkan bahwa TS dan SD tidak berpengaruh signifikan; dan SMTP, SMTA, dan PT berpengaruh secara signifikan, sehingga pengaruh pertumbuhan tingkat pendidikan tenaga kerja terhadap pertumbuhan ekonomi antar daerah adalah setiap 
terjadi kenaikan $1 \%$ pertumbuhan tingkat pendidikan, maka pengaruhnya terhadap pertumbuhan ekonomi antar daerah di Indonesia masing-masing sebesar 0,023719\% dari pekerja TS; $0,122975 \%$ dari tamatan SD; $0,165092 \%$ dari tamatan SMTP; $0,746883 \%$ dari tamatan SMTA; dan 0,115141\% dari tamatan PT. Artinya bahwa kenaikan tingkat pendidikan tenaga kerja akan memicu terhadap pertumbuhan ekonomi karena kenaikan tingkat pendidikan tenaga kerja mengindikasikan telah terjadi kenaikan jumlah tingkat pendidikan tenaga kerja. Dengan kata lain, semakin tinggi tingkat pendidikan akan berdampak pada peningkatan produktivitas sumber daya manusia yang sangat diperlukan dalam proses pembangunan ekonomi. Dengan meningkatnya pendidikan tentuakan memperbaiki kualitas sumber daya manusia yang akan berdampak pada penggunaan modal fisik menjadi lebih efisien dan tenaga kerja akan menjadi lebih produktif. Sehingga dapat menaikkan produktivitas dan pendapatan pekerja maka akan berpengaruh terhadap tingginya pertumbuhan ekonomi.

Hasil perbandingan antara $\mathrm{t}$ hitung dengan ttabel pada variabel pengeluaran pemerintah sektor pendidikan terlihat bahwa thitung > ttabel $(4.739331>1.97472)$ dengan signifkansi $(0.0000<0,05)$ lebih kecil dari tingkat signifikansi $5 \%$ hal ini menunjukkan pengaruh positif dan signifikan, berarti pengeluaran pemerintah sektor pendidikan berpengaruh secara signifikan terhadap pertumbuhan ekonomi. $\mathrm{Hal}$ ini dapat diartikan bahwa meningkatnya pengeluaran pemerintah sektor pendidikan mempengaruhi pertumbuhan ekonomi.

Hasil penelitian ini sesuai dengan hipotesis dan teori human capital, bahwa pengeluaran pemerintah atas pendidikan dapat meningkatkan kualitas penduduk kemudian selanjutnya meningkatkan pertumbuhan ekonomi. Menurut Todaro pengaruh terhadap pertumbuhan ekonomi masih rendah disebabkan karena pengeluaran pemerintah yang 
ditujukan sebagai perbaikan modal manusia pada dasarnya merupakan suatu investasi. Pengeluaran pemerintah atas pendidikan yang akan menghasilkan perbaikan disektor pendidikan tidak dapat secara cepat mengubah kualitas angkatan kerja yang kemudian dapat meningkatkan produktivitas kerja. Setelah pekerja tersebut mendapatkan pelatihan dan pendidikan yang lebih maka produktivitas meningkat sehingga membawa efek pada peningkatan pertumbuhan ekonomi. Hasil penelitian menunjukkan bahwa terdapat pengaruh positif antara pengeluaran pemerintah sektor pendidikan terhadap pertumbuhan ekonomi. Hasil ini memperkuat penelitian sebelumnya yang dilakukan oleh Budi Irawati (2007) di mana ada hubungan positif antara pengeluaran pemerintah sektor pendidikan dengan pertumbuhan ekonomi di Indonesia. Hasil penelitian ini juga memperkuat temuan Wicakti Woro (2009), di mana terdapat hubungan positif antara pengeluaran pemerintah sektor pendidikan terhadap pertumbuhan ekonomi di Indonesia. Pengeluaran pemerintah pada sektor pendidikan tersebut dapat meningkatkan pelayanan dan fasilitas-fasilitas pendidikan seperti bangunan sekolah, buku-buku, kebutuhan laboratorium, ataupun beasiswa untuk murid yang tidak mampu. Dengan demikian, kebijakan pengeluaran pemerintah untuk sektor pendidikan, merupakan investasi yang berujung memperbaiki kualitas manusia. Pendidikan merupakan jalan menuju kemajuan dan pencapaian kesejahteraan sosial dan ekonomi. Selain itu, investasi di bidang pendidikan secara nyata berhasil mendorong kemajuan ekonomi dan menciptakan kesejahteraan sosial. Oleh karena itu, pengeluaran pemerintah untuk sektor pendidikan yang merupakan investasi jangka panjang harus didukung dengan pembiayaan yang memadai dan merata.

Sektor pendidikan dalam APBD pada umumnya mendapat alokasi terbesar sebagai cerminan 
dari prioritas untuk meningkatkan kualitas sumber daya manusia Indonesia dan sesuai dengan amanat konstitusi. Dengan pengalokasian yang baik dan tepat sasaran, investasi untuk sektor pendidikan dapat meningkatkan kualitas manusia yang pada akhirnya dapat mendukung pencapaian pertumbuhan ekonomi. Selain itu, berdasarkan hasil regresi penelitian ini didapatkan pula karakteristik pertumbuhan ekonomi antar Provinsi yang tercermin pada nilai intercept sebagai berikut:

Tabel 4 Intercept Pertumbuhan Ekonomi Perprovinsi di Indonesia

\begin{tabular}{|l|r|}
\hline NAD-C & -7.244074 \\
\hline SUMUT-C & 0.253830 \\
\hline SUMBAR-C & 0.132435 \\
\hline RIAU-C & -2.910926 \\
\hline JAMBI-C & 0.288411 \\
\hline SUMSEL-C & -0.021864 \\
\hline BENGKULU-C & 0.200452 \\
\hline LAMPUNG-C & 0.997259 \\
\hline BANBEL-C & -1.598727 \\
\hline KEPRIAU-C & -2.916076 \\
\hline JAKARTA-C & -0.908333 \\
\hline JABAR-C & 0.715501 \\
\hline JATENG-C & 2.655255 \\
\hline DIY-C & -1.622838 \\
\hline JATIM-C & 1.987530 \\
\hline BANTEN-C & -1.165560 \\
\hline BALI-C & -0.324685 \\
\hline NTB-C & 1.494744 \\
\hline NTT-C & 0.349607 \\
\hline KALBAR-C & 2.297660 \\
\hline KALTENG-C & 1.554601 \\
\hline
\end{tabular}

\begin{tabular}{|l|r|}
\hline KALSEL-C & 1.291886 \\
\hline KALTIM-C & -3.233981 \\
\hline SULUT-C & 1.779438 \\
\hline SULTENG-C & 1.486977 \\
\hline SULSEL-C & 1.548871 \\
\hline SULTENGGARA-C & 1.750403 \\
\hline GORONTALO-C & 2.035486 \\
\hline SULBAR-C & 2.739163 \\
\hline MALUKU-C & -2.289140 \\
\hline MALUTARA-C & -0.528938 \\
\hline PAPBAR-C & 4.325063 \\
\hline PAPUA-C & -5.119431 \\
\hline
\end{tabular}

Sumber: Eviews versi 7, Diolah

Berdasarkan tabel 4. dapat dilihat adanya variasi dari intercept masing-masing provinsi. Intercept digunakan untuk menjelaskan perbedaan individu melalui variabel dependen. Persamaan regresi berganda memiliki nilai intercept yang artinya jika X1 dan X2 berada pada nilai terendah, maka $Y$ akan mengalami pertumbuhan sebesar nilai intercept tersebut. Di mana dalam intercept yang ditunjukkan pada tabel di atas melihat besarnya pertumbuhan ekonomi di Indonesia. Provinsi Papua Barat memiliki intercept tertinggi sebesar 4,325063\% yang artinya jika tingkat pendidikan tenaga kerja dan pengeluaran pemerintah sektor pendidikan berada pada nilai terendah, maka akan menghasilkan pertumbuhan ekonomi sebesar 
4,325063\%. Provinsi lain yang memiliki intercept tinggi adalah Sulawesi Barat sebesar $2,739163 \%$, yang artinya jika tingkat pendidikan tenaga kerja dan pengeluaran pemerintah sektor pendidikan berada pada nilai terendah maka akan menghasilkan pertumbuhan ekonomi sebesar $2,739163 \%$.

Sedangkan intercept terendah yaitu berada di Provinsi Sumatera Selatan sebesar $0,021864 \%$, yang artinya jika tingkat pendidikan tenaga kerja dan pengeluaran pemerintah sektor pendidikan berada pada nilai terendah maka akan menghasilkan pertumbuhan ekonomi sebesar $0,021864 \%$. Provinsi Bali sebesar $0,324685 \%$, yang artinya tingkat pendidikan tenaga kerja dan pengeluaran pemerintah sektor pendidikan berada pada nilai terendah akan menghasilkan pertumbuhan ekonomi sebesar $0,324685 \%$. Tanda positif berarti Provinsi tersebut memiliki nilai produksi yang tidak dipengaruhi oleh faktor- faktor yang terdapat dalam model (tingkat pendidikan tenaga kerja dan pengeluaran pemerintah sektor pendidikan). Selain itu, tanda positif pada koefisien tiap individu juga menunjukkan Provinsi tersebut memiliki pertumbuhan ekonomi yang besar. Hal tersebut terjadi pada Provinsi Aceh, Sumatera Utara, Sumatera Barat, Jambi, Bengkulu, Lampung, Jawa Barat, Jawa Tengah, Jawa Timur, Nusa Tenggara Barat, Nusa Tenggara Timur, Kalimantan Barat, Kalimantan Tengah, Kalimantan Selatan, Sulawesi Utara, Sulawesi Tengah, Sulawesi Selatan, Sulawesi tenggara, Sulawesi Barat, Gorontalo, dan Papua Barat. Sedangkan daerah yang berkoefisien negatif adalah Provinsi Riau, Sumatera Selatan, Kepulauan Bangka Belitung, Kepulauan Riau, Jakarta, DI Yogyakarta, Banten, Bali, Kalimantan Timur, Maluku, Maluku Utara, dan Papua dan Papua Barat. Daerah dengan koefisien tertinggi adalah Provinsi NAD sedangkan yang terendah adalah Provinsi Sumatera Selatan. 
Secara simultan dengan pengujian Fhitung dibandingkan dengan Ftabel, diperoleh nilai Fhitung $=3.255978$ sedangkan Ftabel $=3,90$. Karena Fhitung > Ftabel maka dengan tingkat kepercayaan $95 \% \quad$ tingkat pendidikan tenaga kerja dan pengeluaran pemerintah sektor pendidikan mempengaruhi secara bersama - sama terhadap pertumbuhan ekonomi. Sementara koefisien determinasi $\left(R^{2}\right)$ juga menunjukkan angka sebesar 0.568211 yang berarti variasi dari tingkat pendidikan tenaga kerja (X1) dan pengeluaran pemerintah sektor pendidikan (X2) secara bersamasama menjelaskan pertumbuhan ekonomi (Y) sebesar 56,82\%, sedangkan sisanya sebesar $43,18 \%$.

Berdasarkan uji asumsi klasik yaitu normalitas dapat diketahui bahwa tingkat pendidikan tenaga kerja dan pengeluaran pemerintah sektor pendidikan terhadap pertumbuhan ekonomi dengan menggunakan uji JarqueBerra memiliki distribusi normal dengan probability $0,251184>0,05$.

Meskipun penelitian ini telah berhasil menguji hipotesis yang diajukan, namun penelitian ini belum sepenuhnya sampai pada tingkat kebenaran mutlak. Sehingga tidak menutup kemungkinan untuk dilakukan penelitian lanjutan. Hal tersebut disebabkan masih terdapat keterbatasan dalam penelitian ini, antara lain: (1) Penelitian ini menggunakan data yang masih kurang mewakili masing-masing variabel yang digunakan, khususnya pengeluaran pemerintah pada sektor pendidikan. Selain itu juga peneliti hanya melakukan penelitian dalam jangka waktu yang pendek yaitu tahun 2008 sampai dengan 2012, dan (2) Birokrasi antara pemerintah dengan instansiinstansi terkait yang kurang cooperative dengan pihak peneliti yang sedang melakukan penelitian dan memerlukan data untuk kelengkapan instrumen penelitian. Hal ini dirasakan peneliti masih berbelit-belit sehingga menyulitkan perolehan informasi, serta sumber daya manusia di birokrasi yang 
bersangkutan karena mereka kurang memahami pentingnya informasi yang dibutuhkan para peneliti di bidang ilmu ekonomi.

\section{KESIMPULAN DAN SARAN}

Berdasarkan hasil analisis data dan pembahasan penelitian yang telah diuraikan sebelumnya tentang pengaruh pendidikan tenaga kerja dan pengeluaran pemerintah sektor pendidikan terhadap pertumbuhan ekonomi di Indonesia, maka dapat diambil kesimpulan bahwa:

Pertumbuhan ekonomi Indonesia di tahun 2008 sampai dengan 2012 tergolong dalam kategori rendah yakni berkisar di angka 3.63 persen; (2) seluruh variabel independen mampu menjelaskan keragaman nilai pada variabel pertumbuhan ekonomi sebesar 56,82 persen sedangkan sisanya 43,18 persen dijelaskan oleh variabel - variabel yang berada di luar model penelitian; (3) Pendidikan tenaga kerja berpengaruh positif dan signifikan terhadap pertumbuhan ekonomi
Indonesia pada tahun 2008 sampai dengan 2012, dan (3) Pengeluaran pemerintah sektor pendidikan berpengaruh positif dan signifikan terhadap pertumbuhan ekonomi Indonesia pada tahun 2008 sampai dengan 2012.

Pertumbuhan ekonomi adalah salah satu indikator yang penting dalam melakukan analisis tentang pembangunan ekonomi yang terjadi pada suatu negara. PDRB per kapita atas dasar harga konstan dapat menunjukkan pertumbuhan ekonomi suatu wilayah yang sebenarnya. Indonesia sebagai negara berkembang berupaya meningkatkan pertumbuhan ekonomi melalui peningkatan pendidikan dan dukungan pemerintah. Meningkatnya pendidikan tentu akan memperbaiki kualitas sumber daya manusia yang ditandai dengan meningkatnya ratarata pendidikan yang ditamatkan tenaga kerja di masing-masing provinsi. Selain itu, dibutuhkan perhatian pemerintah yang tercermin dalam realisasi anggaran pendidikan untuk masing-masing 
provinsi. Untuk itu implikasi dari penelitian ini diharapkan pemerintah pusat dan daerah bersama-sama untuk fokus dalam pembentukan sumber daya manusia baru yang dapat menjadi tonggak kemajuan bangsa.

Berdasarkan kesimpulan serta implikasi di atas, maka peneliti menyampaikan saran-saran sebagai berikut: (1) Untuk meningkatkan pertumbuhan ekonomi maka pendidikan tenaga kerja harus ditingkatkan dengan cara: (a) Menyetarakan rata-rata pendidikan yang ditamatkan tenaga kerja di Indonesia yaitu dengan menuntaskan program wajib belajar 9 tahun dan kemudian dilanjutkan dengan program wajib belajar 12 tahun sehingga kualitas sumber daya manusia meningkat; (b) Pembinaan softskill dan lifeskill kepada tenaga kerja baik yang belum tamat sekolah ataupun hanya lulusan sekolah dasar agar dapat bersaing di pasar kerja; (2) Untuk meningkatkan pertumbuhan ekonomi maka pengeluaran pemerintah sektor pendidikan harus ditingkatkan dengan cara: (1) Dalam perencanaan dan pelaksanaan pembangunan, penentu dan pengambil kebijakan hendaknya menentukan prioritas pembangunan pada daerah dan sektor yang yang perlu mendapat penanganan dan perhatian khusus. Sehingga diperlukan koordinasi antara pemerintah provinsi dan kabupaten/ kota untuk menyamakan visi dan misi pembangunannya dalam rangka untuk mencapai kemajuan pembangunan ekonomi dan pendidikan yang merata; (b) Pentingnya pengawasan dalam pengelolaan dan distribusi dana pendidikan agar dana pendidikan tepat sasaran.

\section{DAFTAR PUSTAKA}

Ramirez dan G. Ranis. (1998). Economic Growth and Human Capital. Working Paper No.18.

Ali Mohammad. (2009). Pendidikan untuk Pembangunan Nasional. Jakarta: PT Imperial Bhakti Utama.

Badan Pusat Statistik. (2011). Pendapatan Regional DKI Jakarta. Jakarta: Badan Pusat Statistik Propinsi DKI Jakarta.

Boediono. (1999). Teori Pertum- 
buhan Ekonomi. Yogyakarta: BPFE UGM.

Danim Sudarwan. (1995). Transformasi SDM. Jakarta: Bumi Aksara.

Duane Schultz. (1994). Psikologi Pertumbuhan: Model-Model Kepribadian Sehat. Penerbit: Kanisius.

Dumairy. (1997). Perekonomian Indonesia. Jakarta: Erlangga.

Hg. Suseno Trijanto Widodo. (1990). Indikator Ekonomi. Yogyakarta: Kanisius.

Lubis Rahmah. (2012). Mendongkrak Human Development Indonesia (HDI) atau Indeks Pembangunan Manusia (IPM) Melalui Program Keaksaraan. Jurnal Universitas Pendidikan Indonesia. Bandung.

M.L. Jhingan. (2003). Ekonomi Pembangunan Dan Perencanaan. Jakarta: PT. Raja Grafindo.

Nachrowi. (2006). Pendekatan Populer dan Praktis Ekonometrika untuk Analisis Ekonomi dan Keuangan. Jakarta: LPFE UI.

Suryadi Ace. (1999). Pendidikan Investasi, SDM dan
Pembangunan. Jakarta: Balai Pustaka.

Sukirno Sadono. (2004). Makro Ekonomi Teori Pengantar. Jakarta: RT. Raja Gravindo Persada.

Suryana. (2000). Ekonomi Pembangunan, Problematika dan Pendekatan. Jakarta: Salemba Empat.

Suparmoko. (1994). Keuangan Negara dalam Teori dan Praktek, Edisi keempat. Yogyakarta: BPFE.

Suparman, Abdoel Jalan dan Rozy Munir. (1993). Perkembangan Pembangunan Manusia di Indonesia. Pus.Lit: Pranata Pembangunan IV.

Soemanto Wasty. (2008). Pendidikan Wiraswasta. Jakarta: Bumi Aksara.

http://www.data statistik-indonesia.com

http://www.dikti.go.id/file/atur/UU202003Sisdiknas.pdf

http://www.edukasi.kompas.com/re $\mathrm{ad} / 2014 / 09 / 26 / 13202052 / \mathrm{ma}$ hasiswa.di.in.donesia.Cuma4 ,8.juta

http://www.inherent-dikti.net/file/ sisdiknas.pdf 